\title{
Physicochemical Quality Indicators of Akmay Safflower Oil Cultivated in the Dry Steppe Zone of Northern Kazakhstan
}

\author{
Kazhymurat Mayrambekovich Mussynov ${ }^{1 *}$, Bauyrzhan Kenzhebaevich \\ Arinov ${ }^{1}$, Yerlan Amanzholovich Utelbayev ${ }^{1}$, Berik Bekturevich Bazarbayev ${ }^{1}$ \\ 1 S. Seifullin Kazakh Agrotechnical University, Pobeda Avenue, 62, Astana, 010000, Kazakhstan \\ * Corresponding author's e-mail: mussynovk@bk.ru
}

\begin{abstract}
The article presents the results of the 2014-2015 studies on seed yield and the physicochemical and fatty acid composition of Akmay grade safflower oil cultivated at the experimental plot of LLC "Farmer 2002", Astrakhan district, Akmola region, Kazakhstan. The peroxide and acid number was determined with the titrimetric method with visual indication, and the iodine number was calculated as well. The fatty acid composition of oil was studied using the gas chromatography method. Up to 12 fatty acids were detected in the composition of total lipids. The highest content of fatty acids in the composition of safflower seed oil triglycerides was observed in unsaturated linoleic acid (82.7\%). During the years of research, the weather conditions greatly influenced the seed yield and the physicochemical quality of safflower oil. Conclusions about future use of this variety as raw material for producing edible vegetable oil were drawn.
\end{abstract}

Keywords: safflower oil yield, fatty acid composition, peroxide number, iodine number, acid number.

\section{INTRODUCTION}

Cultivation of safflower goes back to distant antiquity. Dried flowers of safflower were found in the tomb of the Egyptian Pharaoh who ruled the country in the 16th century BC. The name of safflower is found in the dictionary of the ancient Sanskrit language. Almost the entire botanic diversity of this crop is concentrated In India [Meirman \& Abdullayev, 2012].

In ancient countries, safflower was used for obtaining a dyeing substance, carthamin, which was used for dyeing carpets and knitting products. The studies of [Minkevich, 1949; Kupptsov, 1931; Momot, 1935] showed that with the emergence of Aniline dye these dyeing substances lost their value.

According to P.M. Zhukovsky, safflower was originally grown as a dye plant, the proof thereto may be the fabrics dyed with safflower in the 16th century BC, found in Egyptian excavations. Safflower was brought to Europe by Arabs; then, it was brought to Italy, France and Russia [Zhukovsky, 1964].
According to the information from Wang Jau $\mathrm{Mu}$, today safflower is cultivated as oilseed crop in India, China, the USA, Australia, Afghanistan, Iraq and the CIS countries. According to the scientist, the taste and color of safflower oil is not inferior to those of sunflower oil. It is used for making margarine, and the mix of sesame and peanut butter is used for making artificial food yellow oil [Wang, 1993].

Intact plants, flowers, seeds, and butter are widely used for medical purposes in various countries. According to E.A. Weiss, safflower is mainly grown in China for its flowers, which are used as invigorating tea, and in Afghanistan and India, the tea made from safflower leaves is used to prevent infertility and miscarriage in women [Weiss, 1997]. In Iran, the safflower oil is used for liver and heart diseases. In Pakistan, seed decoctions are used with sugar as laxative, for flushing the urinary tract, in Bangladesh, seeds are crushed and mixed with mustard oil to reduce rheumatic pains [Knowles, 1965; Smith, 1996], and in India safflower oil is used for ulcers and rheumatism [Weiss, 1971]. Safflower has laxative 
and choleretic action, including the safflower oil into the diet decreases the level of cholesterol in the blood by $9-15 \%$ in 8 weeks. According to the studies of the Kazakh Academy of Nutrition, safflower oil contains $76-82 \%$ of polyunsaturated linoleic acid called vitamin $F$, which is not synthesized in the body, and only comes with food [Ismuhambetov, 2008].

Linoleic acid plays an important role in the immune process; it promotes excretion of cholesterol by converting it into soluble compounds, increases the resistance to viruses and bacteria, chronic liver diseases, and arthritis. It is also necessary to ensure integrity of the plasma membranes, growth and reproduction, functioning of skin and other organs [Shikov, et al., 2004].

The last decade in the Republic of Kazakhstan has shown a steady trend of increased planting and production of oil crops [Kaskyrbaev, 2013]. Safflower may replace sunflower as an oilseed crop in the arid steppe areas. While safflower was earlier grown mainly in the southern regions of Kazakhstan, currently this crop, due to its unpretentiousness and drought resistance, is sown on increasingly larger in northern regions. The reason for safflower popularity is the fact that it is adapted to the conditions of sharply continental climate and belongs to the most drought-resistant plants [Arinov, et al., 2011].

For the conditions of Northern Kazakhstan the research for developing the technology of safflower cultivation was performed for the first time. However, the quality of the seeds grown in this area was not determined.

Therefore, the authors are interested in studying the chemical composition of Akmay variety safflower grown in the dry steppe zone of Northern Kazakhstan for substantiating the prospects of using it in our country and abroad.

In order to study the composition and physical properties of safflower seed oil, the authors used the Akmay variety of the 2014 and 2015 harvest grown on the best variants according to the results of our research, which was performed in 2012-2014, the optimum sowing date being May 10 , and the optimum seeding rate being 0.25 million germinating seeds per 1 hectare, or $12 \mathrm{~kg}$ per 1 hectare [Mussynov, et al., 2014].

\section{MATERIALS AND METHODS}

The object of the study was unrefined safflower oil made from the seeds of Akmay variety [GOST 10857-64, 2010]. The peroxide number was determined according to [GOST 26593-85, 2014] and the acid number according to [GOST 31933-2012, 2014].

In order to determine the peroxide number and the acid number, the samples of safflower seeds were ground in a "Vyuga" mill for 10 seconds, then the powdered seed sample was placed in a conical flask with a glass stopper, triple amount of chloroform (200 $\mathrm{ml})$ was added into the flask, stirred and left to infuse for 3 hours. After this time, the chloroform extract was filtered through a folded filter and aliquot parts were taken with a pipette, 3 samples $10 \mathrm{ml}$ each: for determining the peroxide number, the acid number, and the weight. The subsample was then set for 24 hours for the chloroform to evaporate, leaving pure oil.

For determining the acid number, $10 \mathrm{ml}$ of alcohol were added to the aliquot, and the content of the flask was subsequently stirred. 2-3 drops of phenolphthalein are then added to the solution. The obtained oil solution had been quickly titrated with $0.1 \mathrm{~mol} / \mathrm{dm}^{3}$ constant concentration sodium hydroxide with constant agitation until slightly pink color was reached. Afterwards, the acid number was calculated according to the following formula:

$$
\mathrm{X}=5.611 * V * K / \mathrm{m}
$$

where: 5.611 was $\mathrm{KOH}$ weight in $1 \mathrm{~cm}^{3}$ of the solution with molar concentration $\mathrm{c}$ $(\mathrm{KOH})=0.1 \mathrm{~mol} / \mathrm{DM}^{3}(0.1 \mathrm{n}) \mathrm{mg}$ when $\mathrm{NaOH}$ was used; then the shares of molar weights of $\mathrm{KOH}$ and $\mathrm{NaOH}$ were obtained by multiplying the calculated weight of $\mathrm{NaOH}$ in $1 \mathrm{~cm}^{3}$ of the solution with molar concentration c $(\mathrm{NaOH})=0.1 \mathrm{~mol} / \mathrm{DM}^{3}$ $(0.1 \mathrm{n})$ equal to 4.0 , by 1.4 ;

$K$ was the ratio of actual to nominal concentration of potassium hydroxide solution or sodium hydroxide;

$V$ was the volume of sodium hydroxide solution with molar concentration $\mathrm{c}=0.1 \mathrm{~mol} / \mathrm{dm}^{3}$ used for titration, $\mathrm{cm}^{3}$; and

$m$ was the weight of the sub-sample, $g$. 
For determining the peroxide number, $15 \mathrm{~cm}^{3}$ of acetic acid and $1 \mathrm{~cm}^{3}$ of potassium iodide were added to an aliquot, then the flask was immediately closed, stirred for $1 \mathrm{~min}$, and left for $5 \mathrm{~min}$ in a dark place at $15-25^{\circ} \mathrm{C}$. Then, $75 \mathrm{~cm}^{3}$ of water were added, stirred and starch solution was added until a violet-blue coloration was reached, and titrated with sodium thiosulfate until a milky-white color was reached, using the solution with molar concentration $\mathrm{c}\left(\mathrm{Na}_{2} \mathrm{~S}_{2} \mathrm{O}_{3} 5 \mathrm{H}_{2} \mathrm{O}\right)=0.002 \mathrm{~mol} / \mathrm{dm}^{3}$. Afterwards, the peroxide number was calculated according to the following formula:

$$
X=\left(V_{1}-V_{0}\right) * c * 1,000 / m
$$

where: $V_{1}$ was the volume of sodium thiosulfate used for measurement, $\mathrm{cm}^{3}$;

$V_{0}$ was the volume of sodium thiosulfate used for reference measurement, $\mathrm{cm}^{3}$; $c$ was the actual concentration of the used sodium thiosulfate solution, calculated with regard to the nominal concentration adjustment, $\mathrm{mol} / \mathrm{dm}^{3}$;

$m$ was the weight of the sub-sample, $g$; and 1,000 was the coefficient for converting the measurement result into millimoles per kilogram.

The method of calculating the iodine number was according to [GOST R ISO 3961-2010, 2014].

The iodine number of Akmay safflower oil was determined based on its fatty acid composition determined by means of fatty acid methyl esters gas chromatography. It is applicable to triglycerides and free fatty acids. In our studies, the value of the iodine number of triglycerides was calculated by means of the following formula:

$$
\begin{aligned}
& W_{11}=W_{16: 1} * 0.950+W_{18: 1} * 0,860+ \\
& +W_{18: 2} * 1.732+W_{18: 3} * 2.616+ \\
& +W_{20: 1} * 0.785+ \\
& +W_{22: 1} * 0.723
\end{aligned}
$$

where: $w_{11}$ were $_{\text {the }}$ triglycerides;

$W_{16: 1}$ was the mass fraction of hexadecanoic acid, \%;

$W_{18: 1}$ was the mass fraction of octadecenoic acid, \%;

$W_{18: 2}$ was the mass fraction of octadecadienoic acid, \%;

$W_{18: 3}$ was the mass fraction of octadecatrienoic acid, \%;
$W_{20: 1}$ was the mass fraction of eicosenoic acid, \%;

$W_{22: 1}$ was the mass fraction of docosenoic acid, \%;

The fatty acid composition was determined according to [GOST 31663-2012, 2014] on a liquid gas chromatograph "Crystal - 2000 M".

The fatty acid composition of the Akmay safflower seed oil was studied with gas-liquid chromatography after converting fatty acids into methyl esters beforehand with the method described in [GOST 31665-2012, 2014]. A sample of pure oil was stirred, then a $0.1 \mathrm{~g}$ sub-sample was dissolved in $2 \mathrm{ml}$ of hexane. Then, $0.1 \mathrm{ml}$ of potassium hydroxide solution in methanol $(5 \%)$ was injected into the hexane solution with a pipette, stirred for 2 minutes and left to settle for 2 minutes. The upper layer of the solution with methyl ether was filtered through a paper filter. Then, it was analyzed on gas chromatograph "Cristal - 2000M" with a flame ionization detector. For this purpose, a $0.5 \mu 1$ sample was taken with a micro-syringe, and injected into the evaporator of the gas chromatograph. Separation by components occurred in the $100 \mathrm{~m}$ long capillary column with internal diameter of $0.25 \mathrm{~mm}$, coated with BR-2560 (Biscuanopropul Polysiloxane) during stationary phase. The fatty acid composition was determined by the time of releasing corresponding to methyl esters in the form of peaks, and with the method of internal normalization the mass fraction (\%) of each methyl ester, i.e. fatty acid, was calculated. The area of all peaks (methyl esters) was summed and taken for $100 \%$; then the area of each peak (methyl ester) was calculated.

\section{RESULTS AND DISCUSSION}

According to the data of agrichemical study performed in 2014, the soil at the experimental field was medium carbonate dark brown soil. The content of humus was $3.0 \%$, of easily hydrolyzable nitrogen $-36.8 \mathrm{mg} / \mathrm{kg}$ of soil; of phosphorus $-19.4 \mathrm{mg} / \mathrm{ha}$, and of potassium $-509 \mathrm{mg} / \mathrm{kg}$.

Humidity constituted the main limiting factor in the area of the experiments. The peculiarities of the sharply continental climate of Northern Kazakhstan manifested themselves during all 
years of the study, significantly reducing the yield of safflower plants.

During the years of the study, the weather conditions in the safflower plants' vegetation period, particularly during the formation of the yield and its quality, were favorable as they were at the level of mean annual indicators (August, September). However, in the initial phase, safflowers were deviating from the average long-term indicators, in 2014, in May and June, the amount of precipitation was 17 and $15 \mathrm{~mm}$ below the mean figures for many years, and in 2015, on the contrary, exceeded the average indicators by 34 and $9 \mathrm{~mm}$. This enabled to form good plant density, compared to 2014. July was favorable, with sufficient rainfall of 72-74 $\mathrm{mm}$ for green mass formation (Figure 1).

During the years of the study, the hydrothermal coefficient that showed humidity of the year (HTC) in the safflower "sowing - maturation" period was estimated as "dry", the coefficient amounted to 0.7 and 0.8 ; however, in the period of "shootsbudding", the coefficient was $0.5-0.6$ in 2014, which corresponded to "very dry", and $0.7-0.8$ in 2015, which corresponded to "dry" on the scale.
The temperature throughout year 2014 was different from the mean indicators for many years. In May, the air temperature was above the average long-term figures by $+2.5^{\circ} \mathrm{C}$ and reached $+15.1^{\circ} \mathrm{C}$, the I and II decades of May were especially hot. The II and III decades of June were hot, the temperature was above the average long-term figures by $+2.5^{\circ} \mathrm{C}$ and reached $+20.4^{\circ} \mathrm{C}$, while the average monthly temperature in July was below the many years' figures by $+1.2^{\circ} \mathrm{C}$, and reached $+18.9^{\circ} \mathrm{C}$, the II and III decades were especially cold, the average air temperature was below the average long-term figures by $+1.6^{\circ} \mathrm{C}$. However, August and September were very hot, and provided sufficient amount of heat for safflower in the period of blooming for the formation and maturation of high-quality seeds.

In 2015, the same behavior was observed in May, June, July, and September, but in August, during safflower seed formation, the average monthly temperature was below the average longterm figures by $+0.7^{\circ} \mathrm{C}$, and reached $+17.2^{\circ} \mathrm{C}$. This period was cool, compared to 2014 , which could affect some quality parameters of safflower oil (Figure 2).

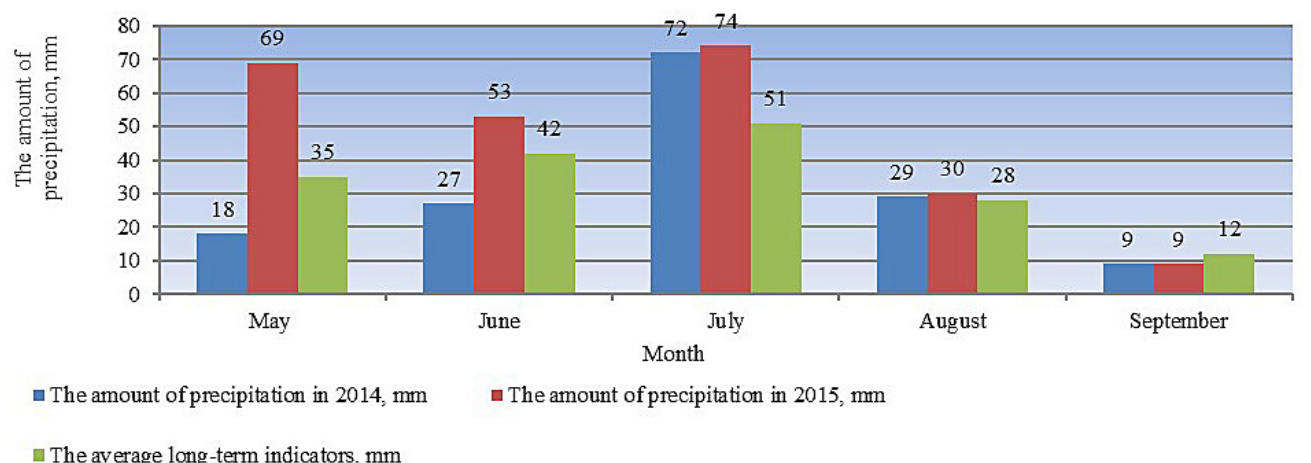

a The average long-term indicators, $\mathrm{mm}$

Figure 1. The amount of precipitation during safflower vegetation season, compared to the many years' figures, $\mathrm{mm}$

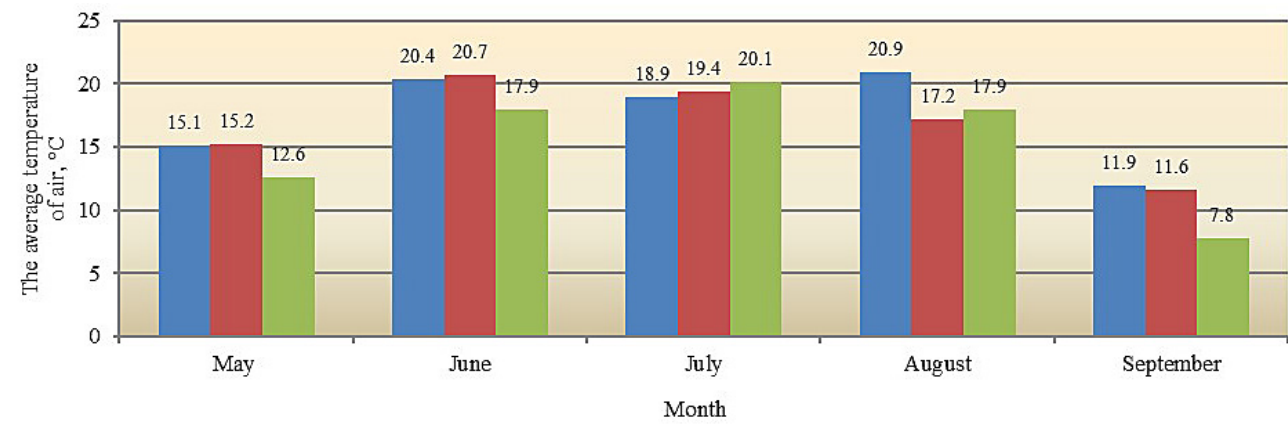

- The average monthly temperature in $2014,{ }^{\circ} \mathrm{C} \quad$ a The average monthly temperature in $2015,{ }^{\circ} \mathrm{C}$

$\square$ The average long-term indicators, ${ }^{\circ} \mathrm{C}$

Figure 2. The average monthly temperature during safflower vegetation period, compared to previous years, ${ }^{\circ} \mathrm{C}$ 
During the years of research higher safflower yields were formed mainly by the number of composite flowers on a single plant, and the weight of 1,000 seeds.

In 2015, especially in the first phases of safflower growth and development, in the "sprouts""branching" - "composite flower formation" periods, the weather conditions were favorable (in terms of the amount of precipitation in May and June) compared to 2014. In 2015, the number of plants in $1 \mathrm{~m}^{2}$ was 18 , the number of composite flowers was 10.3 , and the weight of 1,000 seeds was $39.1 \mathrm{~g}$, which were higher than those in 2014, respectively, by 1.7 plants, 1.9 flowers, and $3.5 \mathrm{~g}$. The structural indicators of the yield were used to calculate the biological productivity, which in 2015 was $15.9 \mathrm{hw} / \mathrm{ha}$ exceeding the 2014 yield by $4.9 \mathrm{hw} / \mathrm{ha} \mathrm{(Table} 1)$.

However, the physicochemical and fatty acid content of the oil was different. Quality indicators of oil of the 2014 yield were high compared to 2015. According to our opinion, it was due to the weather conditions during the period of safflower "formation" and "seeds maturation". During this period in 2014 , the average monthly temperature was higher by $0.7-3.7^{\circ} \mathrm{C}$ compared to 2015 , and the period was classified as "very dry". This showed that in the period of safflower seeds" "formation" and "ripening", formation of high quality seeds required high temperature. As shown by the results of oil physicochemical content analysis, the acid number of the 2015 sample was $6.3 \mathrm{mg} \mathrm{KOH} / \mathrm{g}$, which exceeded the standard figure by $2.3 \mathrm{mg} \mathrm{KOH} / \mathrm{g}$. There were no deviations in terms of other quality indicators (Table 2).

As a result of the analyses, 12 fatty acids were identified: myristic, palmitic, palmitoleic, stearic, oleic, linoleic, linolenic, arachic, gondoinic, behenic, lignoceric, and selacholeic acid.

The results of the analysis performed on gas-liquid chromatograph "Crystal - 2000 M" showed that the fatty acid composition of oil of the Akmay safflower of 2014 grown at the experimental station of LLC "Farmer 2002" in the Astrakhan district of the Akmola region corresponded to the requirements of [GOST 30623-98, 1998] and [ST RK 1428-2005, 2005]. However, the content of linoleic and selacholeic fatty acids in the oil from seeds of the 2015 yield was higher than the standard rate, by $1.7 \%$ and $0.1 \%$, respectively. The peculiarity of Akmay safflower oil was the high content of linoleic acid $-79.3-82.7 \%$, as well as the presence of a small amount of linolenic acid of about $0.1-0.3 \%$ (Table 3 ).

Linoleic acid and linolenic acid belong to the so-called essential fatty acids necessary for normal functioning of the body. These acids come into the organism with food, mainly in the form of complex lipids - triglycerides and phosphatides. By comparison with our analysis result (79.3-82.7\%), the content of linoleic acid in other oil plants is low: coconut oil $-1.5-2.6 \%$; coriander oil - 7.0-7.5\%; mustard oil-14.5-20.0\%; linseed oil - 15.0-30.0\%; cotton oil - 40.0-45.0\%; and sunflower oil $-46.0-60.0 \%$. This shows that safflower oil is a rich source of linoleic acid for humans.

\section{CONCLUSION}

The analyses of Akmay safflower oil showed that the physicochemical parameters of the oil met the requirements of ST RK 1428-2005 and

Table 1. The structure of Akmay safflower yield depending on the weather conditions in 2014 and 2015

\begin{tabular}{|c|c|c|c|c|c|c|}
\hline Crop & Year & $\begin{array}{c}\text { The number } \\
\text { of plants } \\
\text { in } 1 \mathrm{~m}^{2}, \mathrm{pcs}\end{array}$ & $\begin{array}{c}\text { The number of } \\
\text { composite flowers per 1 } \\
\text { plant, pcs }\end{array}$ & $\begin{array}{c}\text { The number of } \\
\text { seeds in 1 composite } \\
\text { flower, pcs }\end{array}$ & $\begin{array}{c}\text { The weight of } \\
1,000 \text { seeds, g }\end{array}$ & $\begin{array}{c}\text { Biological yield, } \\
\text { hw/ha }\end{array}$ \\
\hline \multirow{2}{*}{ Safflower } & 2014 & 16.3 & 8.4 & 22.5 & 35.6 & 11.0 \\
\cline { 2 - 7 } & 2015 & 18.0 & 10.3 & 22.0 & 39.1 & 15.9 \\
\hline
\end{tabular}

Table 2. Physicochemical characteristics of Akmay safflower oil

\begin{tabular}{|l|c|c|c|}
\hline \multirow{2}{*}{ The name of physicochemical indicators } & $\begin{array}{c}\text { Physicochemical characteristics of } \\
\text { safflower oil according to standard } \\
\text { ST RK 1428-2005 }\end{array}$ & $\begin{array}{c}\text { Physicochemical parameters of } \\
\text { the sample }\end{array}$ \\
\cline { 3 - 4 } & not more than 10 & 2014 & 2015 \\
\hline Peroxide number, $\mathrm{mmol}$ of active oxygen $/ \mathrm{kg}$, & not more than 4.0 & 0.95 & 4.0 \\
\hline Acid number, $\mathrm{mg} \mathrm{KOH} / \mathrm{g}$, & $130-155$ & 147.6 & 151.7 \\
\hline lodine number, $\mathrm{gJ}_{2} / \mathrm{l00g}$ & & & 6.3 \\
\hline
\end{tabular}


Table 3. Fatty acid composition of Akmay safflower oil

\begin{tabular}{|c|c|c|c|c|c|}
\hline \multirow{2}{*}{ No. } & Fatty acid name & \multirow{2}{*}{$\begin{array}{c}\text { Fatty acid } \\
\text { index }\end{array}$} & $\begin{array}{c}\text { The fatty acid composition of } \\
\text { safflower oil according to GOST } \\
\text { 30623-98 (mass fraction,\%) }\end{array}$ & \multicolumn{2}{|c|}{$\begin{array}{c}\text { The fatty acid composition of } \\
\text { the sample (mass fraction, \%) }\end{array}$} \\
\hline 1 & Myristic & $\mathrm{C}_{14: 0}$ & up to 1.0 & 0.1 & 2015 \\
\hline 2 & Palmitic & $\mathrm{C}_{16: 0}$ & $2.0-10.0$ & 6.1 & 5.1 \\
\hline 3 & Palmitoleic & $\mathrm{C}_{16: 1}$ & up to 0.5 & 0.1 & 0.1 \\
\hline 4 & Stearic & $\mathrm{C}_{18: 0}$ & $1.0-10.0$ & 2.5 & 1.9 \\
\hline 5 & Oleic & $\mathrm{C}_{18: 1}$ & $7.0-42.0$ & 10.9 & 8.9 \\
\hline 6 & Linoleic & $\mathrm{C}_{18: 2}$ & $55.0-81.0$ & 79.3 & 82.7 \\
\hline 7 & Linolenic & $\mathrm{C}_{18: 3}$ & up to 1.0 & 0.3 & 0.1 \\
\hline 8 & Arachic & $\mathrm{C}_{20: 0}$ & up to 0.5 & 0.2 & 0.3 \\
\hline 9 & Gondoinic & $\mathrm{C}_{20: 1}$ & up to 0.5 & 0.1 & 0.2 \\
\hline 10 & Behenic & $\mathrm{C}_{22: 0}$ & up to 0.5 & 0.1 & 0.3 \\
\hline 11 & Lignoceric & $\mathrm{C}_{24: 0}$ & up to 0.1 & 0.1 & 0.1 \\
\hline 12 & Selacholeic & $\mathrm{C}_{24: 1}$ & up to 0.1 & 0.1 \\
\hline
\end{tabular}

featured low peroxide, acid and iodine numbers; however, the acid number of the 2015 yield oil exceeded the standard value of $2.3 \mathrm{mg} \mathrm{KOH} / \mathrm{g}$. In our opinion, this was due to the weather conditions, since during the period of safflower seeds' formation and ripening in August and September rainfall was higher by $1-2 \mathrm{~mm}$ than in the previous years, and the average monthly air temperature was lower by $0.7-3.7^{\circ} \mathrm{C}$.

While determining the fatty acid composition, it was found that linoleic acid was the dominant fatty acid, with the mass fraction of $79.3-82.7 \%$. The fatty acid composition of the Akmay safflower oil from the dry zone of Northern Kazakhstan met the requirements of GOST 30623-98.

As shown by the results of our research, in the very dry year 2014, the yield of safflower was low (11 hw/ha); however, the quality of oil was high compared to less arid year 2015.

The far from complete list of positive properties of safflower oil substantiates the need for appropriate adjustment of the diet towards increasing safflower oil consumption and shows the prospects of its further study.

\section{Acknowledgments}

The article has been prepared based on the results of the grant project of the Ministry of Agriculture of the Republic of Kazakhstan "Development of the Technology of Cultivating Safflower with Regard to Diversification on Dark Chestnut Soils of Northern Kazakhstan" implemented in 2012-2016, state registration number 0112 RK 01334.
The authors express their gratitude to A. N. Lisitsyn, director of the All-Russian Research Institute of Fats ("VNIIZhirov" Saint-Petersburg, Russia) for help and consultations in determining the quality of Akmay oil in the laboratories of the Institute. The authors are also grateful to director of LLC "Farmer 2002" Pelzer Valery A1exandrovich for providing the experimental site for the research and for providing agricultural machinery.

\section{REFERENCES}

1. Meirman, G.T., Abdullayev, A.A. 2012. Valuable samples of safflower varieties and their use in breeding. The Bulletin of Science, KazAgroInnovation, 7, 10-13.

2. Minkevich, I.A. 1949. Oil-bearing-crops. Moscow: Selkhozizdat, 307-329

3. Kupptsov, A.M. 1931. Safflower. New Oil-bearingcrops VIR: collection of scientific works. Leningrad, 36-41

4. Momot, Y.G. 1935. Oil-bearing crops in Kazakhstan. National economy of Kazakhstan. Alma-Ata, 5, 28-30.

5. Zhukovsky, L.M. 1964. Cultivated plants and their relatives. Leningrad: Kolos, 96 p.

6. Wang, J.M. 1993. Assessing global high-quality safflower materials and their use (in Chinese). Beijing: the Publishing House of Technical Sciences, pp. 484.

7. Weiss, E.A. 1997. Oilseed Corops. Chapters safflower. Longman Group Limited, Logman Hause. London, 216-281. 
8. Knowles, P.F. 1965. Variability in oleic and linoeic acid contenta of safflower oil. Economic Botany, $19,53-62$.

9. Smith, J.R. 1996. Safflower. AOCS Press, Champaign, JL. New-York, pp. 624.

10. Weiss, E.A. 1971. Castor, Sesame and safflower. Bremes and Noble Inc. New-York, 529-744.

11. Ismuhambetov, J.D. 2008. [Safflower pests]. Diagnostics and forecasts, pp. 57-58.

12. Shikov, A., Makarov, V., Ryzhenkov, V. 2004. Vegetable oilsand the oil extracts: technology,standardization, properties. Moscow: Publishing house «Russiandoctor», 264 p.

13. Kaskyrbaev, J.A. 2013. Oil-bearing crops and zero technology of cultivation in Northern Kazakhstan. Diversifying crops and zero technology in arid regions: proceedings of the international Conference, Astana-Shortandy, 109-113.

14. Arinov, K.K., Musynov, K.M., Apushev, A.K., et al. 2011. Crop Production. Textbook. Almaty, pp. 631 .

15. Mussynov, K.M., Kipshakbaeva, A.A., Arinov, B.K., et al. 2014. Producing Capacity of Safflower on DarkBrown Soils of the Northern Kazakhstan. Biosciences Biotechnology Research Asia. December, 11 (3), 1121-1130.
16. Interstate standard. GOST 10857-64. 2010. Oilseed. Methods of determining oil content. Moscow: Standartinform, 70-73.

17. Interstate standard. GOST 26593-85. 2014. Vegetable oils. Method of measuring peroxide number. Moscow: Standartinform, 89-93.

18. Interstate standard. GOST 31933-2012. 2014. Vegetable oils. Methods for determining acid number. Moscow: Standartinform, $8 \mathrm{p}$.

19. Interstate standard. GOST R ISO 3961-2010. 2014. Method of calculating iodine number. Moscow: Standartinform.

20. Interstate standard. GOST 31663-2012. 2014. Vegetable oils and animal fats. Determination of methyl esters of fatty acids mass fraction by gas chromatography. Moscow: Standartinform.

21. Interstate standard. GOST 31665-2012. 2014. Vegetable oils and animal fats. Obtaining methyl esters from fatty acids. Moscow: Standartinform.

22. Interstate standard. GOST 30623-98. 1998. Vegetable oils and margarine products. The method of detecting fraud. Minsk: The Publishing House of Standards.

23. ST RK 1428-2005. 2005. Food Safflower oil. Astana: Memstandart, $8 \mathrm{p}$. 